\title{
BRENTANO Y QUINE: MODALIDADES PSICOLÓGICAS DE RE E INDETERMINACIÓN DE LA TRADUCCIÓN*
}

\author{
THOMAS M. SIMPSON \\ Centro de Altos Estudios \\ en Ciencias Exactas, Argentina
}

En el $\S 45$ de Word and Object $^{1}$ Quine examina de manera ingeniosa la tesis de Brentano sobre la intencionalidad. Pero no se detiene en la versión original de Brentano, quien introdujo la intencionalidad como una característica última de los sucesos mentales (y por lo tanto como un "criterio de demarcación" entre lo mental y lo físico), sino en la versión lingüistica de R. M. Chisholm, que resume en una breve frase: "No existe modo alguno de eliminar el vocabulario intencional analizando sus términos componentes mediante otros términos" de carácter no intencional ( $W O$, p. 220). ${ }^{2}$ La reacción usual de los filósofos conductistas frente a la tesis de Brentano fue un intrépido esfuerzo por elaborar "traducciones" plausibles del lenguaje mentalístico al lenguaje fisicalista. Al exponer las razones de su versión lingüística, Chisholm se dedica a probar, con empeñosa complacencia, el fracaso de tanta intrepidez. Pero Quine, hombre de senti. mientos ${ }^{3}$ proconductistas si los hay, ${ }^{4}$ nos sorprende con esta

\footnotetext{
* Este artículo forma parte de una investigación más amplia realizada de enero a mayo de 1975 en Indiana University (EUA), gracias a una beca de la Fundación Guggenheim. El artículo referido en nota 6 es también resultado de esta investigación.

1 Word and Object, M.I.T. Press, 1960. En adelante, $W O$.

2 Para el planteo del problema por Chisholm, ver su artículo "Oraciones de creencia", incluido en Thomas M. Simpson, Semántica filosófica: problemas $y$ discusiones (Buenos Aires-Madrid: Siglo XXI: 1973).

3 Quise decir "conductas".

4 "Me considero a mí mismo tan conductista como podría serlo cualquiera en sus cabales" ("Reply to Harman", Synthese, p. 268). Esforzándose por defender la tesis de la indeterminación de Quine, Harman había negado la sugerencia de que Quine "fuera un conductista filosófico" (Synthese, diciembre 1968 , p. 22), tratando de "salvarlo" de la acusación de que su teoría "depende de una doctrina tan anacrónica" (loc. cit., p. 22).
} 
afirmación: "Nuestras presentes reflexiones son favorables a esta tesis" ( $W O$, pp. 220-221). Este es el primer paso de su argumentación.

El segundo paso consiste en admitir que el uso de un vocabulario intencional permitiría presentar la traducción como determinada:

Pues empleando las palabras intencionales "creer" y "aplicar" podríamos decir que el término pronunciado por un hablante debe interpretarse como "conejo" si y sólo si el hablante está dispuesto a aplicar tal término a todos los objetos que él cree que son conejos, y solamente a ellos ( $W O$, pp. 220-221; la bastardilla es mía).

¿Qué ocurre entonces con la doctrina de la indeterminación? Por si nos quedaba alguna duda, leemos nuevamente que "la tesis de Brentano [...] es inseparable de [is of a piece with] la tesis de la indeterminación traduccional" ( $W O$, p. 221). Sin embargo, el resultado de esta estrategia sinuosa es un dramático dilema (tercer paso): "Podemos aceptar la tesis de Brentano o bien como mostrando la imprescindibilidad del vocabulario intencional y la importancia de una ciencia autónoma de la intencionalidad, o como mostrando la falta de justificación de los términos intencionales y el carácter vacuo de una ciencia de la intencionalidad" (loc. cit., p. 221). Cuarto paso (golpe final): "Mi actitud, a diferencia de Brentano, es la segunda" (loc. cit., p. 221).

Por supuesto, puede tolerarse todavía el uso del vocabulario intencional en la notación "canónica" de $W O$ si se lo emplea con el objeto de "disolver perplejidades verbales o facilitar la deducción lógica"; ${ }^{6}$ pero si lo que deseamos es

5 ¿Actitud proposicional?

6 Para un análisis detallado de la notación de Quine y de su poder expre- 
"describir la estructura verdadera y última de la realidad, entonces el esquema canónico es para nosotros el austero esquema que sólo admite la cita directa, y ninguna otra, y que no reconoce las actitudes proposicionales sino sólo la constitución física y la conducta de los organismos" ( $W O$, p. 221 ; la bastardilla me pertenece).

Podemos preguntarnos ahora si el verbo "creer" se usa en el texto (A) de manera transparente $u$ opaca. ${ }^{7}$ Parece claro que debemos inclinarnos por el sentido transparente, pues la parte en bastardilla podría reformularse sin distorsiones como: "si y sólo si el hablante está dispuesto a aplicar tal término a todos los objetos $x$ tales que él cree que $x$ es un conejo, y solamente a ellos".

Esta paráfrasis no implica ninguna ontología especial, ya sea de intensiones u oraciones, pues está acuñada en el estilo neutral de la sección 31 de $W O{ }^{8}$ Pero exhibe una cuantificación desde afuera en un contexto de creencia, lo que implica, de acuerdo con las tesis del propio Quine, que se requiere una interpretación de re para redimirla del sinsen. tido. Podemos concluir, entonces, que la univocidad [determinancy] de la traducción queda garantizada si el lenguaje se halla bien equipado para la expresión de la creencia de re,

sivo, cf. Thomas M. Simpson, "Las creencias y el mundo: Sobre las objeciones de Hintikka a Quine", Crítica, Vol. VIII, N²2, 1976, pp. 45-54.

7 Esta forma de plantear la cuestión es aproximada, pero sirve como la célebre escalera que debemos abandonar al final del camino. Ver el artículo citado en nota 6.

$8 \mathrm{El}$ estilo adoptado se usa para evitar el carácter intuitivamente extraño de una paráfrasis como "si y sólo si el hablante está dispuesto a aplicar tal término a todos los objetos $x$ tales que él cree-verdadero de $x \ll x$ es un conejo»", según el estilo de la sección 31 de $W O$, porque se podría pensar que a un extranjero le resultaría imposible creer-verdadera de $x$ una expresión castellana. Pero recuérdese que para Quine esta formulación no presupone que el sujeto al que se atribuye la creencia conozca el lenguaje al que pertenece la expresión entrecomillada o cualquier otro lenguaje; hasta un ratón puede creer-verdadera una oración castellana (o al menos una oraeión inglesa). Por este motivo me inclino a sostener la conjetura piadosa de que el hablante cuyas emisiones traducimos con la palabra "conejo" no se halla en una posición más lastimera que un modesto ratón. Pero el uso del estilo neutral nos ahorra estas sutilezas. Sobre el caso del ratón véase el artículo de Quine, "Cuantificadores y actitudes proposicionales", incluido en mi trabajo, Semántica filosófica (referencias en nota 2). 
cuya salvación fue considerada una tarea apremiante por Quine mismo en otros contextos quizás menos "profundos". Pero como Wesley C. Salmon ha dicho con agudeza iluminadora, "el Modus Ponens de un hombre es el Modus Tollens de otro"," y la actitud de Quine es rechazar in toto el vocabulario intencional (incluyendo su uso transparente o de re) sobre la base de que "aceptar el uso intencional en su valor aparente [...] es postular las relaciones de traducibilidad como siendo de algún modo objetivamente válidas aunque indeterminadas por principio respecto de la totalidad de las disposiciones verbales" ( $W O$, p. 221).

El rechazo final de las actitudes de re puede resultar extraño si recordamos las serias motivaciones que impulsaron a Quine a empeñarse en salvar su respetabilidad lógica: "Sin duda [...] el sentido transparente de la creencia no debe ser descartado con ligereza" (WO, p. 148); los enunciados que formulan creencias de re son en verdad "indispensables" (The Ways of Paradox, p. 189) y "no estamos dispuestos a prescindir de ellos" (loc. cit., p. 186)..$^{10}$

Pero este rechazo arroja una luz retrospectiva sobre el tratamiento dado por Quine a las actitudes psicológicas en $W O$ y "Cuantificadores", y a su modo peculiar de "salvarlas". Después de considerar la propuesta de distinguir dos sentidos de creencia (la opaca y la transparente), Quine nos dice: "Sin embargo, hay un tratamiento más sugerente [...]: aferrarnos de manera uniforme al sentido opaco de creer" ("Cuantificadores", pp. 186-187). ${ }^{11}$ Es difícil evitar la impresión de que la operación de rescate toma aquí un giro sorprendente: ¿no era acaso la opacidad ese perro incivil que introdujo el desorden y las tinieblas en un reino gober.

\footnotetext{
9 Este aforismo profundamente escéptico me llegó a través de Alberto Coffa, quien lo bautizó en algún paper como "El principio de Salmon".

10 Los textos de The Ways of Paradox pertenecen al artículo "Quantifiers and Propositional Attitudes", cuya versión castellana se incluye en mi antología Semántica Filosófica. Seguimos la paginación del original inglés por mera desidia, no por falta de patriotismo. En adelante, nos referiremos a este artículo como "Cuantificadores".

11 Por el énfasis sobre este punto estoy en deuda con Raúl Orayen.
} 
nado por la Generalización Existencial y las claras reglas de sustitución de términos singulares? ¿Por qué aferrarse entonces, precisamente, al sentido opaco de los verbos psicológicos?

La respuesta es que mediante un uso hábil de la opacidad Quine logra el efecto de una transparencia selectiva escribiendo, por ejemplo:

(1) Juan cree $z$ ( $z$ odia a Pedro) de María,

donde " $z$ ( $z$ odia a Pedro)" es el nombre de una intensión, obtenido mediante el procedimiento de abstracción intensional; y la vieja prohibición de cuantificar desde afuera en contextos psicológicos toma ahora la forma de "una regla contra la cuantificación desde afuera en nombres de intensiones" ("Cuantificadores", p. 187). Obsérvese que la figuración de "Pedro" después de "cree" no es puramente referencial, en contraste con la figuración de "María", que está fuera del alcance del verbo.

En este punto de nuestra exposición puede ser útil recordar un argumento de Robert Kirk. ${ }^{12}$ Pues Quine admite el argumento de Kirk en el sentido de que "no hay indeterminación [traduccional] si el lenguaje está bien equipado para la cita indirecta"; ${ }^{13}$ pero aplicando el Principio de Salmon, responde, finalmente, que "la observación de Kirk puede verse no como un modo de poner en tela de juicio la determinación de la traducción, sino el carácter determinado de la cita indirecta" (Synthese, diciembre 1968, p. 267). La indeterminación de la cita indirecta consiste simplemente en el hecho de que "no hay nada que se aproxime a una norma fija acerca de la medida en que una cita indirecta puede desviarse de la directa" ( $W O$, p. 216) sin convertirse en una falsa atribución; y es esto lo que impediría, según Quine,

12 Robert Kirk, "Translation and Indeterminacy", Mind, Vol. LXXVIII, Ne 311, July 1969, pp. 321-341.

13 Synthese, p. 267; la bastardilla es mía. 
efectuar un uso científico de la cita indirecta, así como de las actitudes proposicionales en general.

El punto esencial de esta respuesta consiste en que la cita indirecta es inaceptable a la luz de los criterios de Quine, y no hay manera de aplicar el Modus Ponens para inferir a partir de su aceptación el carácter determinado de la traducción (mostrando así, de paso, que Quine se equivocó en algún punto de su razonamiento). No: la traducción es indeterminada, y en consecuencia, gracias al Modus Tollens, debemos rechazar el empleo de la cita indirecta, si no como medio de expresión en el reino profano de la apariencia cotidiana, al menos en el sacro lenguaje canónico destinado a describir la Realidad última y verdadera.

Antes de proseguir será útil recordar que ya en otros tiempos Quine se había enfrentado con un dilema análogo: la posibilidad de definir la noción de sinonimia a condición de incorporar al lenguaje el adverbio "necesariamente"; pero - se dijo Quine- "¿podemos aceptar un lenguaje que incluye tal adverbio? ¿Tiene realmente sentido tal adverbio?" (From a Logical Point of View, pp. 29-30). Quine se negó, pues, a salvar la sinonimia porque no entendía el adverbio "necesariamente", como ahora se niega a salvar la determinación de la traducción apelando al empleo de la cita indirecta, que está ella misma afectada por el mal de la indeterminación (en el sentido explicando más arriba).

Después de este breve excurso consideremos nuevamente las actitudes de re, incluyendo la contraparte de re de la cita indirecta, que también tiene derecho a la existencia. En verdad, la interpretación de re de un enunciado de cita indirecta podría representarse siguiendo el modelo de (1):

(2) Juan dice $z\left(z\right.$ odia a Pedro) de María. ${ }^{14}$

14 En la sección 44 de $W O$ Quine aplica a la cita indirecta el método de la abstracción intensional, transformando "Juan dice que Cicerón denunció a Catilina" en "Juan dice [Cicerón denunció a Catilina]". $Y$ nos encontramos también con: 
Si examinamos ahora (1) y (2) veremos que el cargo de indeterminación es también aplicable a las actitudes de re, aun si las reformulamos en un estilo ontológicamente neutral (que no mencione ni entidades lingüísticas ni oraciones). A fin de obtener una reformulación uniforme extenderemos a la cita indirecta de re una sugerencia atribuida por Quine a Davidson ( $W O$, p. 150, n. 2 ); en tristísimo castellano, las oraciones resultantes son: ${ }^{15}$

( $\left.{ }^{\prime}\right)$ Por Juan, María es creída odiar a Pedro;

$\left(2^{\prime}\right)$ Por Juan, María es dicha odiar a Pedro.

$\mathrm{Y}$ con respecto a $\left(1^{\prime}\right)$ y $\left(2^{\prime}\right)$ podemos repetir ahora la acusación de Quine: "No hay nada que se aproxime a una norma fija acerca de la medida en que una cita indirecta de re puede desviarse de la directa"; en otros términos: acerca de la medida en que la expresión que sigue a "es dicha" puede desviarse de la cita literal del predicado aplicado de hecho por Juan a María, y cuánto podemos cambiar la expresión que sigue a "es creída" y referirnos aún a la creencia de Juan acerca de María.

En consecuencia, Quine tiene razones para sostener que en la hora del Juicio Final, del Gran Balance metafísico-

(i) Juan dice-verdadera "Cicerón denunció a Catilina"

como una reformulación del uso de dicto de la cita indirecta; pero no hay nada como

(ii) Juan dice-verdadero "denunció a Catilina" de Cicerón,

que, dicho sea al pasar, resulta más natural que la anterior formulación (2), en que se emplea la abstracción intensional. Sea como fuere, es razonable suponer que la notación canónica de Quine (en el estilo de las secciones 35 o 44 de $W O$ ) debe permitir la expresión de la cita indirecta de re. Pues es un hecho, compatible con las intuiciones fundamentales de Quine, que usual. mente informamos, mediante una cita indirecta, que alguien dijo algo de cierta persona, por difícil que pueda ser hallar una manera gramaticalmente honorable de distinguir los usos de dicto y de re del discurso indirecto. En rigor, Quine mismo sugiere que éste es el caso cuando dice: "Las construcciones 'cree que...', 'dice que...' (...), etc., son lo que Russell llama actitudes proposicionales. Lo que hemos observado acerca de la primera de ellas en las páginas anteriores se aplica igualmente al resto" ( $\mathscr{W} O$, p. 150).

${ }_{15}$ En problemático inglés, los originales de $\left(1^{\prime}\right)$ y $\left(2^{\prime}\right)$ son, respectivamente: "By Tom, Peter is believed to hate John" y "By Tom, Peter is said to hate John". 
gnoseológico, las actitudes de dicto y de re se encuentran en el mismo bote: el de la opacidad, que es una forma insidiosa de la indeterminación semántica. Pero en cierto modo esto debió de haber sido claro desde el principio, pues la propuesta fundamental de Quine no fue distinguir dos sentidos de los verbos que expresan actitudes proposicionales, sino una teoría de los grados de opacidad; y el punto crucial es que la opacidad no es nunca eliminable del todo, pues afecta inevitablemente a los predicados contenidos en las oraciones intencionales de re.

Quizás convenga postular aquí, por razones de simplicidad, la existencia de un personaje por lo menos bifronte, compuesto por un Quine profano y un Quine esotérico. Desde la nueva perspectiva de los problemas planteados por la indeterminación de la traducción, se puede ver retrospectivamente que la operación de rescate de las modalidades psicológicas de re, por empeñosa y brillante que haya sido, fue obra del Quine profano, y no sobrepasaba el reino provisario de la Apariencia. Con la indeterminación de la traducción apareció en escena el Quine esotérico, quien mostró la profunda fragilidad de aquella operación, realizada por un hombre afectado todavía por los negocios del mundo fenoménico.

En un texto de 1968, el último Quine duda de "que las actitudes proposicionales sean menos oscuras" que la noción de analiticidad; su empresa salvadora no se debió a que "fueran más claras, sino a que eran menos claramente prescindibles: no podemos abjurar de nuestra referencia diaria a la creencia, a menos que dispongamos de un sustituto todavía no previsto" ("Reply to Follesdal", Synthese, 1968, p. 306). Y cuando David Kaplan sugirió la existencia de una asimetría no explicada entre el tratamiento dado por Quine a las modalidades lógicas -que condenó in toto-y las modalidades psicológicas, cuya interpretación de re consideró apremiante salvar (inclusive en un texto relativamente tardío como $W O$ ), Quine se mantuvo firme en su respuesta: "Pese a su oscuridad, la noción de creencia es más útil que 
la de necesidad ... El quid reside en que algunas nociones oscuras son, en virtud de su utilidad, más dignas de que se intente salvarlas" ("Reply to Kaplan", Synthese, p. 314). Como ya hemos visto, tal salvación sólo tenía por objeto "disolver perplejidades verbales y facilitar la deducción" ( $W O$, p. 221); sólo eso y nada más. ¿Conocía o presentía el Quine profano de "Cuantificadores y actitudes proposicionales" la inutilidad gnoseológica y metafísica de la empresa, cuyo fracaso ha sido tan hábilmente expuesto por el Quine esotérico?*

- Deseo expresar mi agradecimiento a Guadalupe García, quien produjo una cuidadosa versión mecanografiada de mis desprolijos originales, tanto en castellano como en inglés, iluminando asi los días grises de octubre con una lucecita de buena voluntad y eficacia. T.M.S. 
In $\S 45$ of Word and Object, Quine deals with Brentano's intentionalist thesis in an ingenious way. He adopts Chisholm's version of Brentano's thesis: "There is no breaking out of the intentional vocabulary by explaining its members in other terms" (p. 220). As was to be expected, the usual behavioristic-minded reaction was a blatant rejection of the claim and a strenuous effort to "translate" mentalistic language into a physicalist one. But the behavioristicminded Quine says: "Our present reflections are favorable to this thesis" (pp. 220-221). This is the first (and unexpected) step of his move.

The second step is to admit that the use of the intentional vocabulary would "represent" translation as determined:

For using the intentional words "believe" and "ascribe" one could say that a speaker's term is to be construed as "rabbit" if and only if the speaker is disposed to ascribe it to all and only the objects that he believes to be rabbits (pp. 220-221; my italics).

What then of the indeterminacy doctrine? We learn again that "Brentano's thesis (...) is of a piece with the thesis of indeterminacy of translation" (p. 221). But the upshot of this mischievous strategy is a dramatic dilemma (third step) : "One may accept Brentano's thesis either as showing the indispensability of intentional idioms and the importance of an autonomous science of intention, or as showing the baselessness of intentional idioms and the emptiness of a science of intention" (p. 221). Fourth (and final step) : "My attitude, ${ }^{1}$ unlike Brentano's, is the second" (p. 221).

Of course, we can still "tolerate" the use of these idioms in the canonical notation of $W O$ if the aim is "to dissolve verbal perplexities or facilitate logical deduction"; but "if we are limming the true and ultimate structure of reality the canonical scheme for us is the austere scheme that knows no quotation but direct quotation and no propositional attitudes but only the physical constitution and behavior of organisms" (p. 221, my italics).

Now, we may ask whether "believe" is used in (A) above in the transparent or the opaque sense. It seems clear that we should interpret it in the transparent one, for the italicized part could be

1 Propositional attitude? 
fairly rephrased as "if and only if the speaker is disposed to ascribe it to all and only objects $x$ such that the speaker believes $x$ to be a rabbit".

This rephrasal does not imply any special ontology, either of intensions or sentences, as it is framed in the neutral style of $W O$ 's $\S 31$. Furthermore, we have here a quantification into the belief context, and then, according to Quine's doctrine, if Quine's text makes sense at all it must be given a de re interpretation. We may conclude, then, that determinacy of translation is guaranteed if the home language is well equipped for the expression of de re belief, whose salvation was considered by Quine a vital task in other (less "deep") contexts.

But as Wesley C. Salmon wittingly says, "one man's modus ponens is another man's modus tollens"; and Quine's attitude is to reject in toto the intentional idioms (including the de re employment of them) on the ground that "to accept intentional usage at face value is (...) to postulate translation relations as somehow objectively valid though indeterminate in principle relative to the totality of speech dispositions" (WO, p. 221).

This final rejection of the de re attitudes may seem in some sense an odd result if we remember the serious motivations which prompted Quine's attempt to rescue the logical respectability of the de re attitudes; "Surely (...) the transparent sense of belief is not to be slightly dismissed" ( $W O$, p. 148) ; the de re statements of belief are indeed "indispensable" ("Quantifiers", p. 189) and "we scarcely prepared to sacrifice [them]" ("Quantifies", p. 186). But it throws a retrospective light on Quine's treatment of attitudes in "Quantifiers..." and $W O$. After considering the proposal of distinguishing two senses of belief (the opaque and the transparent one) he says: "But there is a more suggestive treatment...": "to adhere uniformly to [the opaque] sense of belief" ("Quantifiers", pp. 186-7). In this "uniform sense", Quine obtains the effect of selective transparence by writing, for example:

(1) Ralph believes $z$ ( $z$ hates John) of Ortcutt;

and the prohibition to quantify into psychological contexts takes the form "of a rule against quantifying into names of intensions" ("Quantifiers", p. 187).

A reference to Robert Kirk may prove useful here. For Quine admits Kirk's argument to the effect that "there is no indeterminacy if the home language is well equipped for indirect quotation" (Quine's words: Synthese, p. 267; my italics) ; but applying again Salmon's Principle he replies that "Kirk's observation can be seen as challenging not the indeterminacy of translation but the deter- 
minacy of indirect quotation" (Synthese, p. 267), this latter consisting in the fact that "there is nothing approaching a fixed standard of how far an indirect quotation may deviate from the direct" $(W O$, p. 216) ; and it is this that prevents us from making "scientific sense" of it, and, by similar considerations, of propositional attitudes generally.

Consider now the de re attitudes, including also the de re counterpart of indirect quotation, which has as much a right to existence as the indirect version; indeed, the de re interpretation could be represented according to the pattern of (1), as follows:

(2) Ralph says $z$ ( $z$ hates John) of Ortcutt.

Looking at (1) and (2) we may see that the charge of indeterminacy is also applicable to the de re attitudes, even if we reformulate them in an ontologically neutral style. In order to get a uniform reformulation I will extend to the de re use of "indirect quotation" a suggestion credited to Davidson ( $W O$, p. 150 , footnote 2); the resulting sentences are:

(1') By Ralph, Ortcutt is believed to hate John.

(2') By Ralph, Ortcutt is said to hate John.

Now we can say once again: "There is nothing approaching a fixed standard of how far an indirect de re quotation may deviate from the direct", that is, how far the expression after "said to" in (2') may deviate from the liberal quotation of the predicate actually ascribed by Ralph to Ortcutt, and how far we can change the expression after "believed to" and still refer to Ralph's belief about Ortcutt. So Quine has reasons for maintaining that, when all is said and done, the de dicto and de re attitudes are in the same boat. But in a certain sense this should have been clear from the outset, for Quine's main proposal was not to distinguish two senses of the idioms of propositional attitudes, but a theory of grades of opacity; and the crucial point is that opacity can never be fully eliminated, because it is inevitably attached to the predicates involved in the de re intentional sentences. 